\title{
Article \\ Effect of Storage Conditions and Cooking Methods on Chlorophyll, Glucosinolate, and Sulforaphane Content in Broccoli Florets
}

\author{
Junwei Wang ${ }^{1,2,3,+}$, Shuxiang Mao ${ }^{1,2,3,+}$, Yiming Yuan ${ }^{1,2,3}$, Na Zhang ${ }^{4}$, Qi Wu ${ }^{1,2,3}$, Mantian Liang ${ }^{1,2,3}$, \\ Shengze Wang ${ }^{1,2,3}$, Ke Huang ${ }^{1,2,3, *}$ and Qiuyun $\mathrm{Wu}^{1,2,3, *}$
}

check for

updates

Citation: Wang, J.; Mao, S.; Yuan, Y.; Zhang, N.; Wu, Q.; Liang, M.; Wang,

S.; Huang, K.; Wu, Q. Effect of Storage Conditions and Cooking Methods on Chlorophyll, Glucosinolate, and Sulforaphane Content in Broccoli Florets. Horticulturae 2021, 7, 519. https://doi.org/10.3390/

horticulturae7120519

Academic Editor: Elazar Fallik

Received: 16 September 2021

Accepted: 21 November 2021

Published: 24 November 2021

Publisher's Note: MDPI stays neutral with regard to jurisdictional claims in published maps and institutional affiliations.

Copyright: (c) 2021 by the authors Licensee MDPI, Basel, Switzerland. This article is an open access article distributed under the terms and conditions of the Creative Commons Attribution (CC BY) license (https:// creativecommons.org/licenses/by/ $4.0 /)$
1 College of Horticulture, Hunan Agricultural University, Changsha 410128, China; JunweiWang87@126.com (J.W.); 18374878831@163.com (S.M.); yuanyiming0624@163.com (Y.Y.); wuqi19920729@126.com (Q.W.); liangmt0115@163.com (M.L.); wszxlh2021@163.com (S.W.)

2 Engineering Research Center for Horticultural Crop Germplasm Creation and New Variety Breeding, Ministry of Education, Changsha 410218, China

3 Key Laboratory for Vegetable Biology of Hunan Province, Changsha 410128, China

4 National Engineering and Technology Research Center for Preservation of Agricultural Products, Tianjin Key Laboratory of Postharvest Physiology and Storage of Agricultural Products,

Tianjin 300192, China; 13642125862@163.com

* Correspondence: huangke@hunau.edu.cn (K.H.); qiuyunwu@hunau.edu.cn (Q.W.)

+ Co-first author.

Abstract: The effects of storage conditions and cooking methods on chlorophyll, glucosinolate (GSL), and sulforaphane content in broccoli florets were investigated in this study. For the storage experiment, fresh broccoli florets were stored for 2,4 , and 6 days at 10,4 , and $0{ }^{\circ} \mathrm{C}$ with or without 1-methylcyclopropene (1-MCP) treatment. For the cooking experiment, fresh broccoli florets were cooked for 1, 3, 5, 7, and 9 min under three cooking methods, namely, steaming, microwaving, and boiling. Results showed that the contents of chlorophyll, aliphatic GSL, indole GSL, and sulforaphane in broccoli florets of two cultivars decreased with prolonged storage time. The retained contents of chlorophyll, GSLs, and sulforaphane under $0{ }^{\circ} \mathrm{C}$ storage condition were significantly higher than those under $10^{\circ} \mathrm{C}$ storage condition after 6 days of storage. The sulforaphane content was increased by 1-MCP treatment but differed among varieties. The cooking experiment showed that aliphatic GSL content decreased with increased cooking time under three cooking methods, and indole GSL and sulforaphane contents had a fluctuating trend with increasing cooking time after steaming and microwaving. Sulforaphane content increased by $17.15-50.16 \%$ relative to that in fresh broccoli florets and was considerably affected by cooking time. The highest level of sulforaphane content was retained for $7 \mathrm{~min}$ during steaming or $5 \mathrm{~min}$ during microwaving. Therefore, the combination of 1-MCP treatment and $0{ }^{\circ} \mathrm{C}$ storage condition had the best performance in preserving chlorophyll, GSLs, and sulforaphane. Moreover, steaming for $7 \mathrm{~min}$ or microwaving for $5 \mathrm{~min}$ is a more effective method for preserving the quality and increasing the sulforaphane content of broccoli florets than boiling.

Keywords: broccoli; storage; cooking; glucosinolate; sulforaphane

\section{Introduction}

Broccoli (Brassica oleracea var. italica) contains high levels of vitamins, minerals, polyphenols, and a group of phytochemicals named glucosinolates (GSLs), and it has been characterized with a high nutritional value [1]. GSLs are sulfur-rich, secondary metabolites characteristic of the Brassicales order with important biological and economic roles in plant defense and human nutrition [2-4]. These compounds have gained renewed interest as their major hydrolysis products, such as sulforaphane, exert chemoprotective effects through the action of the endogenous enzyme myrosinase [5]. The most abundant 
GSLs in broccoli is glucoraphanin (GRA), which can be hydrolyzed into sulforaphane by myrosinase [6]. Sulforaphane can effectively prevent or reverse cancers, hepatic, steatosis, and cardiovascular diseases [7-10].

Broccoli has high respiration and transpiration rates, making it highly perishable [11]. This results in substantial economic losses and poses a challenge to post-harvest storage, logistics, and supply management [12]. Therefore, storage conditions are essential for delaying decay and preserving quality of the fresh product. Many post-harvest handling methods have been investigated to extend the shelf life and retain the nutraceutical values of broccoli [13-15]. GSL biosynthesis at the development stage or degradation at the storage stage is a complex process. The effect of post-harvest on GSLs [15-17] has been widely studied, whereas few studies have explored sulforaphane. The green color and high GSL content of broccoli florets are usually maintained through low-temperature storage or with an inhibitor of ethylene synthesis (1-methylcyclopropene, 1-MCP) treatment. These two ways inhibit chlorophyll and GSL degradation, which can maintain green color, extend the shelf life, and delay GSL degradation during storage [18-21]. However, few studies have focused on the effect of temperature or 1-MCP treatment on sulforaphane content during storage in broccoli florets.

Cooking method is another factor to affect GSL or sulforaphane degradation before broccoli florets are eaten. In general, broccoli is prepared at home for convenience and taste preference rather than for the retention of nutrients and health-promoting compounds. Boiling and microwaving are common cooking methods in Western societies, whereas steaming and frying are common in China. Boiling results in severe GSL loss probably through thermal degradation $[1,22,23]$. Steaming and microwaving vegetables produced conflicting results, and the GSL content change is time-dependent for different cooking methods $[22,24,25]$. Therefore, an optimum time for steaming or microwaving may increase or preserve GSLs or sulforaphane bioavailability and prevent their breakdown during prolonged heating.

Accordingly, this study aims to investigate the influences of three storage temperatures $\left(10,4\right.$, and $\left.0{ }^{\circ} \mathrm{C}\right)$ with/without 1-MCP treatment and cooking methods (and time) on color, GSLs, and sulforaphane content of broccoli. Optimizing the storage condition and cooking time can help improving the nutritional value of broccoli florets.

\section{Materials and Methods}

\subsection{Plant Materials and Treatment}

The experiment was carried out in a natural climate greenhouse at Hunan Agriculture University, Changsha, China, from 30 August 2019 to 6 March 2020. Broccoli (Brassica oleracea L. var. cv Yanxiu and Xiangsan No.3) seeds were sowed in plastic trays (50 cells, one seedling per cell) containing substrates on 30 August 2019 and cultivated in a greenhouse with natural climate. Yanxiu and Xianglv No.3 are broccoli varieties with low and high sulforaphane content, respectively. After the full development of the fourth leaf, the plants were randomly transferred to plastic pots containing $10 \mathrm{~L}$ of substrates (peat: vermiculite: perlite $=2: 1: 1)$ on 2 October 2019. A total of 200 plants from each variety were used. After 1 week of pre-culturing, the seedlings were fertilized with full-strength Hoagland's nutrient solution at five-day intervals, and $1 \mathrm{~L}$ of nutrient was applied for per plant. After $80 \%$ broccoli budding, 1.5 high-strength Hoagland's nutrient solution was used as fertilizer at five-day intervals until harvesting. The broccoli florets with $13-15 \mathrm{~cm}$ diameters and uniform size, without pests and mechanical damage, were harvested. The harvested florets were used in the subsequent experiment.

In this experiment, three biological replications were employed for each treatment. Two broccoli florets were mixed for per sample. Fresh broccoli florets were used as control samples. In detail, the mature broccoli plants cultured in plastic pots were moved to the laboratory. Then, the plants were randomly divided into 10 groups (one fresh floret group, six storage groups, and three cooking groups). The florets were cut and then were immediately stored or cooked. For storage without and with 1-MCP treatment, fresh 
broccoli florets were divided into six groups, and three groups were immediately placed in an airtight container (length $\times$ width $\times$ height $=1 \mathrm{~m} \times 1 \mathrm{~m} \times 1 \mathrm{~m}$ ) fumigated with the 1-MCP powder (Aladdin, Shanghai, China) at 10,4 , and $0{ }^{\circ} \mathrm{C}$ for $24 \mathrm{~h}$. The final concentration of evaporated 1-MCP inside the container (volume $1 \mathrm{~m}^{3}$ ) was $10 \mu \mathrm{g} / \mathrm{L}$. Then, the florets were packed with $0.02 \mathrm{~mm}$ PE film at the corresponding storage temperatures. The three other groups were subjected to the same treatment but were not fumigated with 1-MCP. All broccoli florets were stored under darkness for 2, 4, and 6 days after harvest. At the same time, a group for the determination of chlorophyll, GSLs, and sulforaphane content of fresh broccoli florets was selected.

For the cooking experiment, broccoli florets were cleaned and cut into $2 \mathrm{~cm}$ pedicels for the three cooking treatments (boiling, steaming, and microwaving). For the boiling treatment, $200 \mathrm{~g}$ of broccoli pedicels were immersed in $3 \mathrm{~L}$ of boiling water. For the steaming treatment, $200 \mathrm{~g}$ of broccoli pedicels were evenly spread out without any overlap on a stainless-steel steamer basket and transferred into $3 \mathrm{~L}$ of boiling water. For the microwave treatment, $200 \mathrm{~g}$ of broccoli pedicels were placed on a plate and covered with a paper towel soaked in $50 \mathrm{~mL}$ of water, and then cooked in a microwave oven at $700 \mathrm{~W}$. All cooked broccoli samples were treated for 1, 3, 5, 7, and 9 min, and then immediately transferred into an ice water bath for cooling, packed in a bag, and stored immediately in an ultralow-temperature refrigerator at $-80{ }^{\circ} \mathrm{C}$ until they were used in measuring GSL and sulforaphane contents.

\subsection{Chlorophyll Content Measurement}

Chlorophyll was extracted from broccoli florets with a mixture containing acetone, ethanol, and water $(4.5: 4.5: 1, v / v / v)$. Chlorophyll content was measured according to the method as described by Inskeep and Bloom [26]. Briefly, approximately $10 \mathrm{~g}$ of broccoli florets (fresh and stored for 2, 4, and 6 days without and with 1-MCP treatment) was dipped in $100 \mathrm{~mL}$ of the above mixture until they turned white to extract the chlorophyll a and $\mathrm{b}$ content in a dark condition. The absorbance of the extract liquor was determined by a microplate reader at 645 and $663 \mathrm{~nm}$. The chlorophyll content was calculated as follows: chlorophyll content $(\mathrm{mg} / \mathrm{g})=7.84 \times$ OD663 $+20.21 \times$ OD645. Measurements were performed thrice, and the obtained results were expressed as milligram of total chlorophyll per gram of tissue.

\subsection{Determination of GSLs Content}

GSLs were quantified according to a previously described procedure with minor modification [27]. Approximately $500 \mathrm{mg}$ of broccoli floret powder was transferred into two $15 \mathrm{~mL}$ tubes and extracted with $4 \mathrm{~mL}$ of $70 \%$ methanol at $75^{\circ} \mathrm{C}$ for $20 \mathrm{~min}$. Then, $0.1 \mathrm{~mL}$ of internal standard (sinigrin, $5 \mathrm{~mol} / \mathrm{L}$ ) was added to each sample. After the GSLs extract were cooled, $2 \mathrm{~mL}$ of $0.4 \mathrm{~mol} / \mathrm{L}$ barium acetate was added, and the mixture was centrifuged. The supernatant was transferred into a $10 \mathrm{~mL}$ volumetric flask. Subsequently, the sample was mixed with $3 \mathrm{~mL}$ of $70 \%$ methanol and centrifuged. The supernatant was transferred into a flask to a volume of $10 \mathrm{~mL}$ for desulfoglucosinolate isolation through anion-exchange chromatography. DEAE Sephadex A- 25 was preactivated with $2 \mathrm{mmol} / \mathrm{L}$ acetic acid, and $0.5 \mathrm{~mL}$ of DEAE Sephadex A-25 anion-exchange resin was used to fill a $2.5 \mathrm{~mL}$ column for the purification of the extracted GSLs. The column was washed twice with $1 \mathrm{~mL}$ of water before extract loading. Afterward, $5 \mathrm{~mL}$ of the crude extract was placed onto the column, and then washed twice with $1 \mathrm{~mL}$ of water. Desulfoglucosinolate was then released on the column by adding $0.5 \mathrm{~mL}$ of sulfatase solution $(0.5 \mathrm{mg} / \mathrm{mL})$. The column was then closed and incubated at room temperature overnight for desulfation. On the following day, the column was washed with $3 \mathrm{~mL}$ of deionized water for the collection of desulfated GSLs.

Chromatographic and detection conditions were optimized as previously described by Kim et al. [27]. HPLC (California, USA, Agilent, 1260) instrument and Agilent C18 analytical column $(250 \mathrm{~mm} \times 4.6 \mathrm{~mm}, 5 \mu \mathrm{m})$ were used. The mobile phase consisted of 
water (A) and methanol (B). Chromatography was performed at a flow rate of $1 \mathrm{~mL} / \mathrm{min}$ at $30{ }^{\circ} \mathrm{C}$ with the following elution program: the first step at linear gradient from $0 \% \mathrm{~B}$ to $20 \%$ for $25 \mathrm{~min}$, and then linear gradient from $20 \%$ B to $30 \%$ B for $10 \mathrm{~min}$, isocratic elution $90 \%$ B for $10 \mathrm{~min}$, and equilibration of $0 \%$ B for $5 \mathrm{~min}$. The injection volume of samples was $40 \mu \mathrm{L}$. Desulfated GSLs were detected by a diode array detector at $229 \mathrm{~nm}$ and mass spectrometer with QTOF. The source conditions were as follows: capillary, $3.5 \mathrm{kV}$; cone, $30 \mathrm{~V}$; extractor, $5 \mathrm{~V}$; source temperature, $120^{\circ} \mathrm{C}$; and desolvation temperature, $350{ }^{\circ} \mathrm{C}$. The spray was stabilized by a cone gas flow of $100 \mathrm{~L} / \mathrm{h}$, and the desolvation gas flow was adjusted to $750 \mathrm{~L} / \mathrm{h}$. Compounds were identified by comparing the MS data (retention time, ions, and confirmation transition). An internal standard (sinigrin, Sigma-Aldrich, St. Louis, MO, USA) was used for the quantitation of desulfated GLs in accordance with ISO 9167-1 and the method of Schonhof et al. [28].

\subsection{Determination of Sulforaphane Content}

SF was extracted and quantified as described by Huang et al. [29]. Approximately $2 \mathrm{~g}$ of floret powder sample was transferred into a flask with $4 \mathrm{~mL}$ of deionized water and incubated at room temperature for $4 \mathrm{~h}$. The products were extracted with $40 \mathrm{~mL}$ of dichloromethane by shaking three times at $5 \mathrm{~min}$ intervals. Anhydrous sodium sulfate was added to the dichloromethane fraction for the further purification of SF in a funnel. The filtered solution was vacuum-dried in a rotary evaporator at $38^{\circ} \mathrm{C}$. The dried products were eluted with $2 \mathrm{~mL}$ of acetonitrile (HPLC grade).

The eluted SF was cryopreserved at $-20^{\circ} \mathrm{C}$. Before determination, the eluted solution was filtered through a $0.22 \mu \mathrm{m}$ filter to an autosampler vial. Sulforaphane was determined using the Agilent 1260 Series high-performance liquid chromatography system. The determination parameters were as follows: mobile phase, $20 \%$ acetonitrile and $80 \%$ water; wavelength, $240 \mathrm{~nm}$; column temperature, $30{ }^{\circ} \mathrm{C}$; injection volume, $10 \mu \mathrm{L}$; column, C18 reversed-phase column; flow rate, $1 \mathrm{~mL} / \mathrm{min}$; and time, $30 \mathrm{~min}$. The standard (SF, SigmaAldrich, St. Louis, MO, USA) was used for quantitation.

\subsection{Statistical Analysis}

In this study, the results were displayed as mean \pm standard deviation (SD) of three replicates. All data were subjected to an analysis of variance (one-way ANOVA) by SPSS 20.0 statistical software (SPSS Inc., Chicago, IL, USA). Duncan's test $(p<0.05)$ was performed to observe differences between the treatment means. Retained ratio of chlorophyll, GSL, and sulforaphane contents were calculated according to the following formula: Retained ratio $(\%)=$ Content after storage or cooking/Content of fresh broccoli $\times 100 \%$.

\section{Results}

\subsection{Effects of Storage Condition on Chlorophyll Content in Broccoli Florets}

Under different storage conditions, chlorophyll contents in broccoli florets of two varieties continuously decreased with increasing storage time. For the 'Yanxiu' variety, the decrease rate of chlorophyll content from samples stored at 4 and $0{ }^{\circ} \mathrm{C}$ were lower than that at $10^{\circ} \mathrm{C}$, and chlorophyll contents under $4{ }^{\circ} \mathrm{C}$ and $0{ }^{\circ} \mathrm{C}$ storage conditions were significantly higher during the entire storage period (Figure 1A). For 'Xianglv No. $3^{\prime}$, no significant difference in chlorophyll content was found among the three storage temperature conditions on the second and fourth day of storage. However, the content under the $0{ }^{\circ} \mathrm{C}$ condition was significantly higher than those at $4{ }^{\circ} \mathrm{C}$ and $10{ }^{\circ} \mathrm{C}$ only on the sixth day of storage (Figure 1B).

1-MCP is a gaseous ethylene action inhibitor and has been widely used to extend the storage lives of many vegetables and retain quality. Under 1-MCP treatment, the chlorophyll contents in broccoli florets of 'Yanxiu' were significantly higher than those of the control samples in the entire storage period. However, the change was nonsignificant for 'Xianglv No.3'. In comparison with the chlorophyll contents of fresh broccoli florets, retained ratio of chlorophyll content was $90.9 \%$ for 'Yanxiu' and $84.0 \%$ for 'Xianglv No.3' 
under $0{ }^{\circ} \mathrm{C}$ after 1-MCP treatment. Therefore, $0{ }^{\circ} \mathrm{C}$ storage condition and 1-MCP treatment had good effects on broccoli chlorophyll preservation.
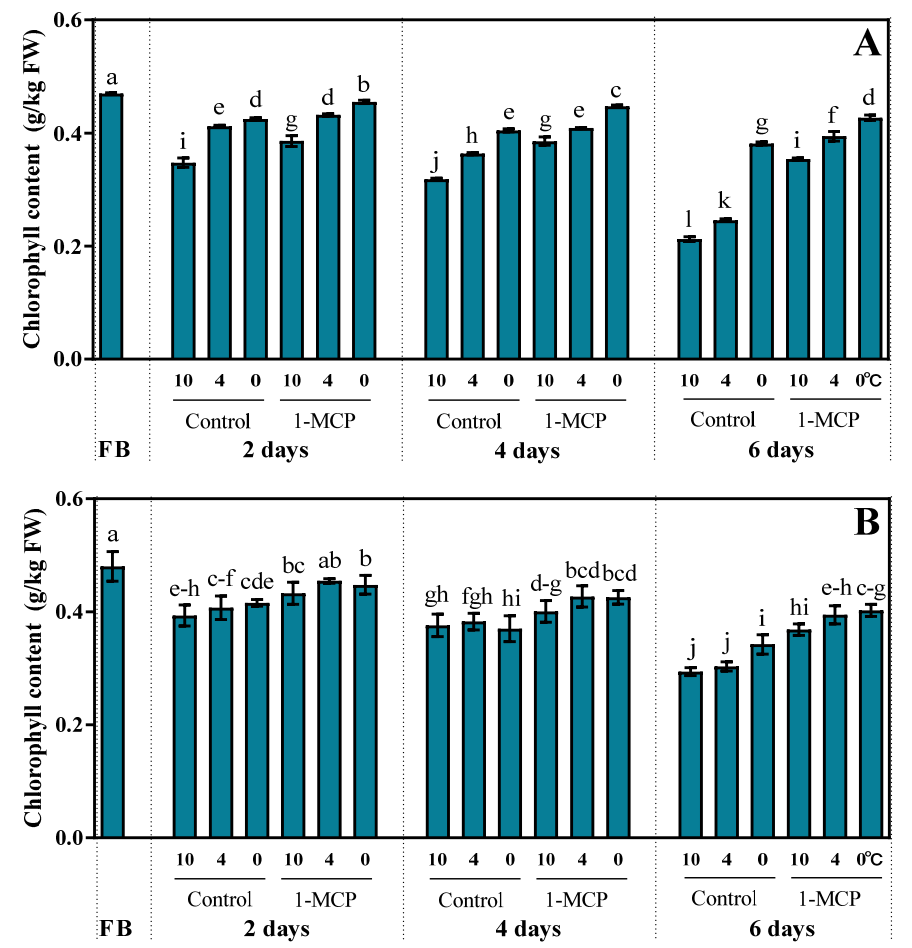

Figure 1. Effects of storage temperature and 1-MCP treatment on chlorophyll content in broccoli florets. (A) Yanxiu, (B) Xianglv No.3. Storage temperature: 10, 4, and $0{ }^{\circ} \mathrm{C}$; control: without 1-MCP treatment; 1-MCP: 1-MCP treatment; FB: the fresh broccoli florets; storage time: 2, 4, and 6 days. Error bars represent $\mathrm{SD}$ from three replications of under every treatment under storage experiment. Different letters indicate statistically significant differences among treatments $(p<0.05)$.

\subsection{Effect of Storage Condition on GSL Content in Broccoli Florets}

The effect of storage temperature on GSL content in broccoli florets of the two varieties is shown in Figure 2. Seven kinds of GSLs were identified in the broccoli florets through HPLC (Table S1). Three GSLs were aliphatic GSLs (AGS), and four were indole GSLs (IGS).

The total GSL content in the 'Xianglv No.3' cultivar was $28.74 \mu \mathrm{mol} / \mathrm{g}$ DW and was significantly higher than that in the 'Yanxiu' cultivar $(18.92 \mu \mathrm{mol} / \mathrm{g}$ DW) at harvest time (Figure 2A,B). The total GSL contents in broccoli florets of the two cultivars continuously decreased with increasing storage time under different storage conditions. In 'Yanxiu', the total GSL contents under 4 and $0{ }^{\circ} \mathrm{C}$ conditions were significantly higher than those under $10^{\circ} \mathrm{C}(p<0.05)$ during the whole storage period. The total GSL contents after 6 days of storage were $6.60\left(10{ }^{\circ} \mathrm{C}\right), 9.69\left(4{ }^{\circ} \mathrm{C}\right)$, and $11.22\left(0^{\circ} \mathrm{C}\right) \mu \mathrm{mol} / \mathrm{g} \mathrm{DW}$, which were $34.9 \%$, $51.2 \%$, and $59.3 \%$ of the values at harvest time, respectively. The data showed that the total GSL contents under 0 and $4{ }^{\circ} \mathrm{C}$ storage conditions were $70.0 \%$ and $46.8 \%$ higher than those under $10^{\circ} \mathrm{C}$ storage condition, respectively. For 'Xianglv No.3', at the sixth day of storage, the total GSL contents of broccoli florets were $13.22 \mu \mathrm{mol} / \mathrm{g}$ DW $\left(10{ }^{\circ} \mathrm{C}\right), 17.69 \mu \mathrm{mol} / \mathrm{g}$ DW $\left(4{ }^{\circ} \mathrm{C}\right)$, and $20.44 \mu \mathrm{mol} / \mathrm{g}$ DW $\left(0{ }^{\circ} \mathrm{C}\right)$, which were $46.0 \%, 61.6 \%$, and $71.1 \%$ of those at harvest time, respectively. The contents at 0 and $4{ }^{\circ} \mathrm{C}$ were $54.6 \%$ and $33.8 \%$ higher than those under $10{ }^{\circ} \mathrm{C}(p<0.05)$, respectively. At the sixth day of storage, 1-MCP treatment significantly increased the total GSL contents of the two varieties under 10 and $4{ }^{\circ} \mathrm{C}$ relative to that of the control group. The increasing effect was not significant under $0{ }^{\circ} \mathrm{C}$, and the retained ratio of total GSL contents after 1-MCP treatment were $10.2 \%$ and $4.6 \%$ higher than those in the control group for the two varieties. 

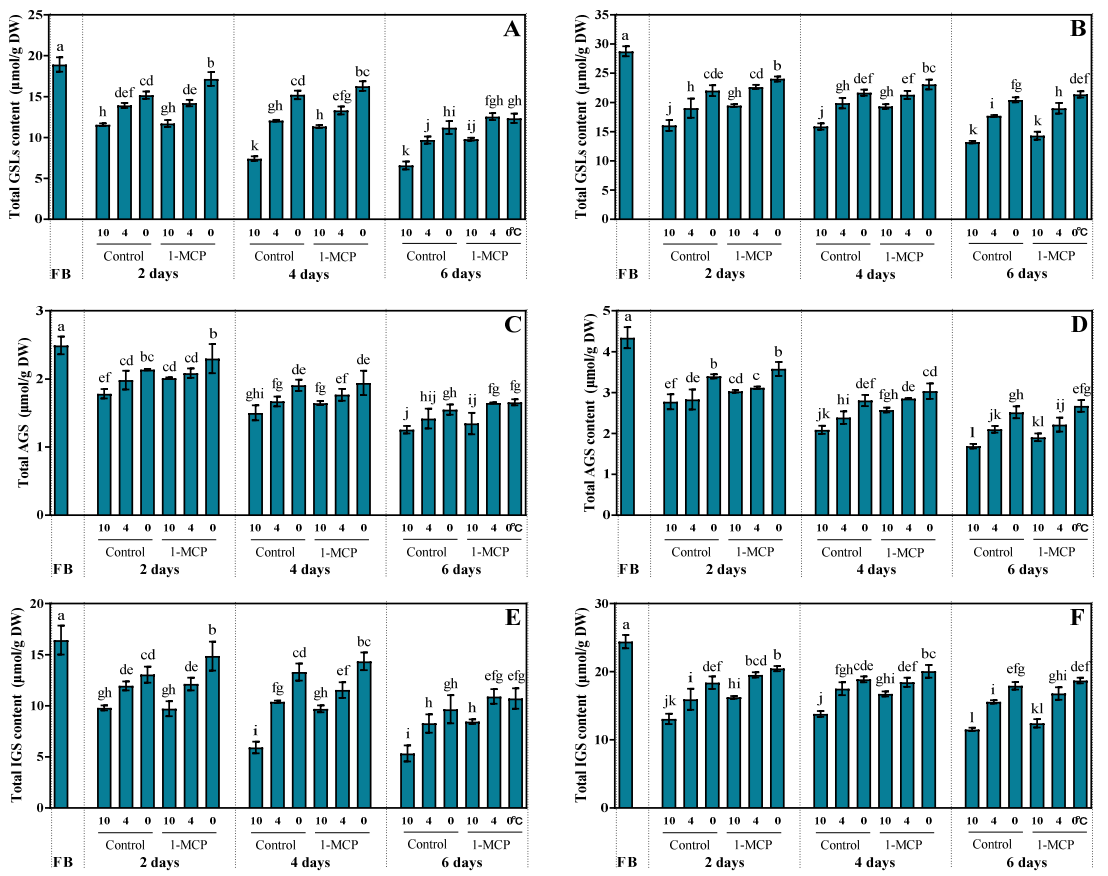

Figure 2. Effects of storage temperature and 1-MCP treatment on GSL content in broccoli florets. Total GSL ((A): Yanxiu, (B): Xianglv No.3), AGS ((C): Yanxiu, (D): Xianglv No.3), IGS content (E): Yanxiu, and (F): Xianglv No.3). Storage temperature: 10,4 , and $0{ }^{\circ} \mathrm{C}$; control: without 1 -MCP treatment; 1-MCP: 1-MCP treatment; FB: fresh broccoli florets; storage time: 2, 4, and 6 days. Error bars represent SD from three replications of under every treatment under storage experiment. Different letters indicate statistically significant differences among treatments $(p<0.05)$.

The contents of AGS and IGS decreased with increasing storage time (Figure 2C-F). The contents of AGS and IGS of the 'Yanxiu' florets were 2.49 and $16.43 \mu \mathrm{mol} / \mathrm{g} \mathrm{DW}$, respectively. In 'Xianglv No.3' florets, the AGS content was $4.34 \mu \mathrm{mol} / \mathrm{g}$ DW, and the IGS content was $24.40 \mu \mathrm{mol} / \mathrm{g}$ DW. For 'Yanxiu', the retained ratios of AGS contents were $50.6 \%\left(1.26 \mu \mathrm{mol} / \mathrm{g} \mathrm{DW}, 10^{\circ} \mathrm{C}\right), 57.0 \%\left(1.42 \mu \mathrm{mol} / \mathrm{g} \mathrm{DW}, 4{ }^{\circ} \mathrm{C}\right)$, and $62.2 \%(1.55 \mu \mathrm{mol} / \mathrm{g}$ $\left.\mathrm{DW}, 0{ }^{\circ} \mathrm{C}\right)$, while the retained ratios of IGS contents were $32.5 \%\left(10^{\circ} \mathrm{C}\right), 50.33 \%\left(4{ }^{\circ} \mathrm{C}\right)$, and $58.9 \%\left(0{ }^{\circ} \mathrm{C}\right)$ at the sixth day of storage. AGS and IGS contents under 4 and $0{ }^{\circ} \mathrm{C}$ storage conditions had no significant difference but were significantly higher than those under $10{ }^{\circ} \mathrm{C}$ storage condition. For 'Xianglv No.3', the retained ratio of AGS contents were $38.9 \%$ $\left(1.69 \mu \mathrm{mol} / \mathrm{g} \mathrm{DW}, 10{ }^{\circ} \mathrm{C}\right), 48.5 \%\left(2.10 \mu \mathrm{mol} / \mathrm{g} \mathrm{DW}, 4{ }^{\circ} \mathrm{C}\right)$, and $58.0 \%(2.52 \mu \mathrm{mol} / \mathrm{g} \mathrm{DW}$, $0{ }^{\circ} \mathrm{C}$ ) after the sixth day of storage, whereas the retained rates of IGS contents were $47.3 \%$ $\left(10{ }^{\circ} \mathrm{C}\right), 63.9 \%\left(4{ }^{\circ} \mathrm{C}\right)$, and $73.5 \%\left(0{ }^{\circ} \mathrm{C}\right)$. The AGS and IGS contents under the $0{ }^{\circ} \mathrm{C}$ storage conditions were significantly higher than those under the 4 and $10^{\circ} \mathrm{C}$ storage conditions. Therefore, low temperature enhanced the delay of AGS and IGS degradation.

For 'Yanxiu', the average AGS contents in the control and 1-MCP-treated groups were 1.41 and $1.55 \mu \mathrm{mol} / \mathrm{g}$ DW, respectively, at the sixth day of storage, while the average IGS contents were 7.76 and $10.02 \mu \mathrm{mol} / \mathrm{g}$ DW. For 'Xianglv No.3', the AGS contents in the control and 1-MCP-treated group were 2.10 and $2.27 \mu \mathrm{mol} / \mathrm{g}$ DW, respectively, and the IGS contents were 15.02 and $15.97 \mu \mathrm{mol} / \mathrm{g}$ DW at the sixth day of storage. Statistical analysis showed that 1-MCP treatment increased AGS and IGS contents by $4.31-58.1 \%$ for the two varieties compared with those in the control group at the sixth day of storage.

The variation trend of most individual GSL content profiles was similar to that of total GSL, which continuously declined with increasing storage time. The content of 4hydroxyglucobrassicin $(4 \mathrm{OH})$ and 4-methoxyglucobrassicin (4ME) in the broccoli florets of the two varieties had peak values at the fourth day of storage (Figure S1). The results suggested that $4 \mathrm{OH}$ and $4 \mathrm{ME}$ were biosynthesized or converted during storage. Moreover, IBE cannot be detected in the 'Xianglv No.3' broccoli florets due to its low content. 


\subsection{Effect of Storage Condition on Glucoraphanin and Sulforaphane Content in Broccoli Florets}

GRA contents in the broccoli florets for the two varieties decreased with increasing storage time (Figure 3A,B). The GRA contents in the 'Yanxiu' and 'Xianglv No.3' florets were 2.08 and $3.97 \mu \mathrm{mol} / \mathrm{g}$ DW at harvest time, respectively. The content in 'Xianglv No. $3^{\prime}$ was approximately twice that of 'Yanxiu'. After 6 days of storage, the retained ratio of GRA content were $50.5 \%\left(1.05 \mu \mathrm{mol} / \mathrm{g} \mathrm{DW}, 10^{\circ} \mathrm{C}\right), 57.7 \%\left(1.20 \mu \mathrm{mol} / \mathrm{g} \mathrm{DW}, 4{ }^{\circ} \mathrm{C}\right)$, and $63.0 \%$ $\left(1.31 \mu \mathrm{mol} / \mathrm{g} \mathrm{DW}, 0{ }^{\circ} \mathrm{C}\right)$ in the 'Yanxiu'. The content under the $0{ }^{\circ} \mathrm{C}$ storage condition was significantly higher than that under $10^{\circ} \mathrm{C}$, but no significant effect was observed under $4{ }^{\circ} \mathrm{C}$. The retained ratio of GRA contents in 'Xianglv No.3' were approximately $40.6 \%$ $\left(1.61 \mu \mathrm{mol} / \mathrm{g} \mathrm{DW}, 10^{\circ} \mathrm{C}\right), 50.9 \%\left(2.02 \mu \mathrm{mol} / \mathrm{g} \mathrm{DW}, 4^{\circ} \mathrm{C}\right)$, and $60.5 \%\left(2.40 \mu \mathrm{mol} / \mathrm{g} \mathrm{DW}, 0{ }^{\circ} \mathrm{C}\right)$. The contents under $0{ }^{\circ} \mathrm{C}$ storage condition was $18.8 \%$ and $49.1 \%$ higher than that at 4 and $10{ }^{\circ} \mathrm{C}$, respectively $(p<0.05)$. During the whole storage process, the retaining GRA content at $0{ }^{\circ} \mathrm{C}$ was higher than that at 4 and $10{ }^{\circ} \mathrm{C}$, and the $0{ }^{\circ} \mathrm{C}$ storage temperature was the best storage condition for the two broccoli varieties for GRA retention. In comparison with the control group, the average GRA content in 1-MCP-treated group at the sixth day storage increased by approximately $13.4 \%$ for 'Yanxiu' and $7.5 \%$ for 'Xianglv No.3'. However, no significant difference was observed between the 1-MCP-treated and control groups.
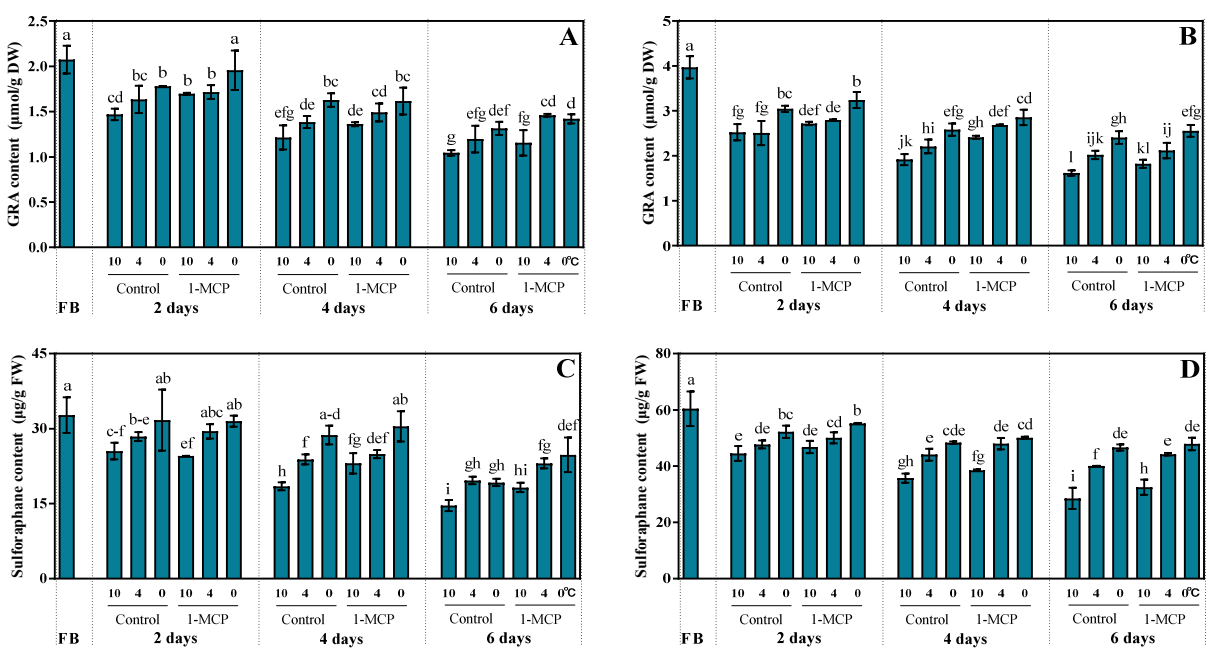

Figure 3. Effects of storage temperature on glucoraphanin and sulforaphane content in broccoli florets. Glucoraphanin content ((A): Yanxiu, (B): Xianglv No.3), sulforaphane content ((C): Yanxiu, (D): Xianglv No.3). Storage temperature: 10,4 , and $0{ }^{\circ} \mathrm{C}$; control: without 1-MCP treatment; 1-MCP: 1-MCP treatment; FB: fresh broccoli florets; storage time: 2, 4, and 6 days. Error bars represent SD from three replications of under every treatment under storage experiment. Different letters indicate statistically significant differences among treatments $(p<0.05)$.

Under different storage conditions, the sulforaphane contents in broccoli florets of the two varieties showed a downward trend with prolonged storage time (Figure 3C,D). At harvest time, sulforaphane contents in 'Yanxiu' and 'Xianglv No.3' were 32.72 and $60.43 \mu \mathrm{g} / \mathrm{g}$ FW, respectively. After 6 days of storage, the sulforaphane contents in 'Yanxiu' were 14.62, 19.63 , and $19.23 \mu \mathrm{g} / \mathrm{g} \mathrm{FW}$ under 10,4 , and $0{ }^{\circ} \mathrm{C}$ conditions, retaining approximately $44.7 \%$, $60.0 \%$, and $58.8 \%$ of the contents at harvest time, respectively. The contents under 0 and $4{ }^{\circ} \mathrm{C}$ storage conditions were $31.5 \%$ and $34.3 \%$ higher than those under $10{ }^{\circ} \mathrm{C}$. For ' Xianglv No. $3^{\prime}$, the sulforaphane contents were $28.56\left(10^{\circ} \mathrm{C}\right), 40.03\left(4^{\circ} \mathrm{C}\right)$, and $46.63 \mu \mathrm{g} / \mathrm{g} \mathrm{FW}\left(0^{\circ} \mathrm{C}\right)$ after 6 days of storage, retaining approximately $47.3 \%, 66.2 \%$, and $77.2 \%$ of the contents at harvest time, respectively. The content under the 4 and $0{ }^{\circ} \mathrm{C}$ storage condition was significantly higher than that under $10{ }^{\circ} \mathrm{C}$. In comparison with $10{ }^{\circ} \mathrm{C}$ storage condition, 4 and $0^{\circ} \mathrm{C}$ storage conditions enhanced the retention of sulforaphane in broccoli. In comparison with the average sulforaphane content in the control group, the average sulforaphane content in 1-MCP-treated group at 6 th day storage increased by approximately $23.4 \%$ for 
'Yanxiu' and approximately $8.15 \%$ for 'Xianglv No.3'. A significant increase was found in the 1-MCP-treated and control groups for 'Yanxiu', but no significant increase was found for 'Xiangsan No.3'. Therefore, 1-MCP treatment can delay sulforaphane degradation in broccoli florets during storage, but the effect depends on the variety.

\subsection{Effects of Cooking Method on GSL Content in Broccoli Florets}

With prolonged cooking time, the change trends of total GSL content in the broccoli florets varied among the three different cooking methods (Figure 4A,B). For boiling, total GSL content decreased with cooking time. However, the content first decreased, and then increased, and finally decreased after $7 \mathrm{~min}$ of steaming or microwaving. At $7 \mathrm{~min}$, the contents in 'Yanxiu' were 16.15 and $11.57 \mu \mathrm{mol} / \mathrm{g}$ DW after steaming and microwaving, respectively, and $3.29 \mu \mathrm{mol} / \mathrm{g}$ DW after boiling. The contents in 'Xianglv No.3' were 24.59 (steaming), 16.44 (microwave), and $5.49 \mu \mathrm{mol} / \mathrm{g}$ DW (boiling). Statistical analysis results show that the total GSL content in broccoli florets for the two varieties at 7 min under steaming and microwaving was significantly higher than that under boiling $(p<0.05)$.
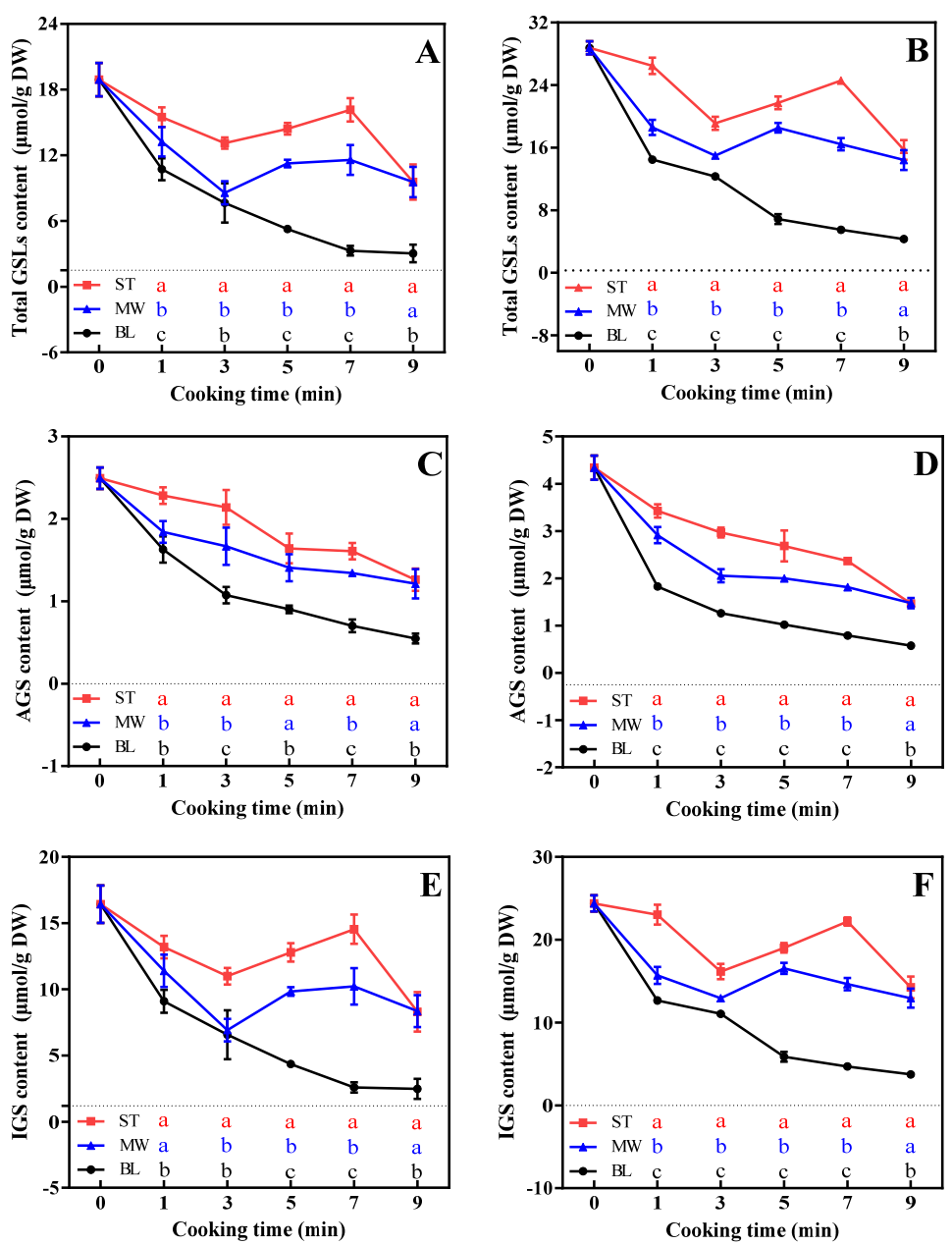

Figure 4. Effects of cooking method on GSL content in broccoli florets. Total GSL content ((A): Yanxiu, (B): Xianglv No.3), total AGS content ((C): Yanxiu, (D): Xianglv No.3), total IGS content ((E): Yanxiu, and (F): Xianglv No.3). Red lines, steaming, blue lines, microwaving; black lines, boiling. Error bars represent SD from three replications of under every treatment under cooking experiment. Different letters indicate statistically significant differences among treatments $(p<0.05)$.

The total IGS content of the broccoli florets had a similar trend compared with the total GSL content. The maximum value at $7 \mathrm{~min}$ was obtained through steaming and microwaving, and the content continuously decreased during boiling (Figure 4E,F). Unlike the total 
GSL content, the AGS content continuously decreased with cooking time (Figure 4C,D). The AGS contents in 'Yanxiu' were 1.61 (steaming), 1.34 (microwave), and $0.70 \mu \mathrm{mol} / \mathrm{g}$ DW (boiling), retaining $64.7 \%, 53.8 \%$, and $28.1 \%$ of their original values at $7 \mathrm{~min}$, respectively. In 'Xianglv No.3', the AGS contents were 2.37, 1.81, and $0.79 \mu \mathrm{mol} / \mathrm{g}$, respectively, which decreased by $54.6 \%, 41.7 \%$, and $18.2 \%$, respectively. The AGS contents after steaming or microwaving were higher than that after boiling, and the highest value was obtained through steaming. Steaming and microwave methods could better retain the beneficial secondary metabolites in broccoli. For cooking broccoli, steaming and microwave methods are better than the traditional method of boiling.

For different cooking methods and time, the variation trend of individual profile GSL content was inconsistent. Notably, with prolonged cooking time, GER was not detected due to the values below the detection limit of HPLC, after boiling 'Yanxiu' for $3 \mathrm{~min}$ and 'Xianglv No.3' for $5 \mathrm{~min}$. The contents of $4 \mathrm{OH}$, and glucobrassicin (GBC) in the broccoli florets of the two varieties had minor wave trends, but reached the highest levels under steaming at different cooking times (Figure S2).

\subsection{Effects of Cooking Method on Glucoraphanin and Sulforaphane Contents in Broccoli Florets}

GRA content in broccoli florets had a trend similar to that of AGS content. The content continuously decreased with increasing cooking time (Figure 5A,B). The GRA contents in 'Yanxiu' were 1.30 (steaming), 0.92 (microwave), and $0.53 \mu \mathrm{mol} / \mathrm{g}$ DW (boiling), retaining approximately $62.5 \%, 44.2 \%$, and $25.5 \%$ of their original values at $7 \mathrm{~min}$. In 'Xianglv No.3', the GRA contents were 2.25, 1.69, and $0.79 \mu \mathrm{mol} / \mathrm{g}$, respectively, retaining $56.7 \%, 42.6 \%$, and $19.9 \%$ of their initial values, respectively.
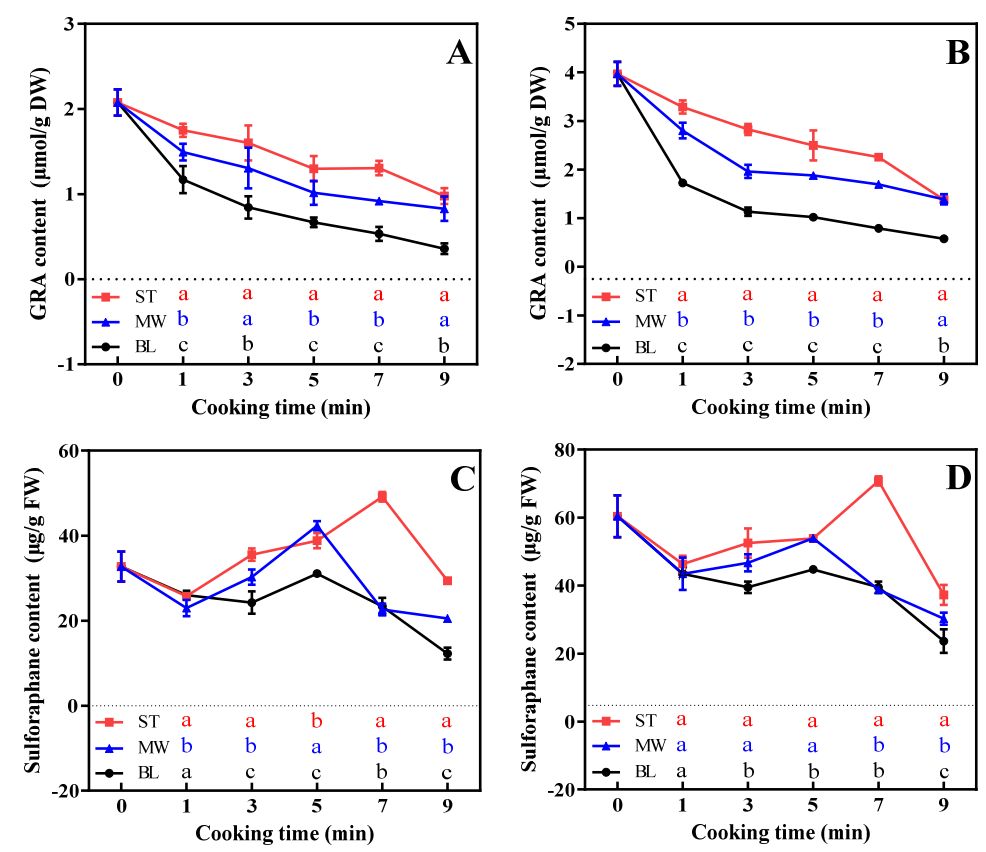

Figure 5. Effects of cooking method on glucoraphanin and sulforaphane contents in broccoli florets. Glucoraphanin content ((A): Yanxiu, (B): Xianglv No.3), sulforaphane content ((C): Yanxiu, (D): Xianglv No.3). Red lines, steaming, blue lines, microwaving; black lines, boiling. Error bars represent SD from three replications of under every treatment under cooking experiment. Different letters indicate statistically significant differences among treatments $(p<0.05)$.

Sulforaphane content in broccoli florets first decreased, then increased, and finally decreased with increasing cooking time in the three cooking methods, similar to AGS content (Figure 5C,D). In the boiling method, sulforaphane contents in the two varieties showed high rates of increases at $5 \mathrm{~min}$, but the values were lower than those obtained at $0 \mathrm{~min}$. In the microwave method, sulforaphane contents in the two varieties showed 
high rates of increases at $5 \mathrm{~min}$. The content increased by $29.40 \%$ relative to that in the fresh florets of 'Yanxiu' but decreased by $10.8 \%$ relative to the content in 'Xianglv No.3'. For steaming, sulforaphane contents in the two varieties reached their peaks at $7 \mathrm{~min}$ $(49.13 \mu \mathrm{g} / \mathrm{g}$ in 'Yanxiu' and $70.79 \mu \mathrm{g} / \mathrm{g}$ in 'Xianglv No.3'). The values increased by $50.16 \%$ and $17.15 \%$ relative to those of fresh florets. However, the sulforaphane contents of the two varieties decreased rapidly at $9 \mathrm{~min}$. The sulforaphane contents of the two broccoli varieties can reach high levels with prolonged cooking time and were significantly higher than the content obtained through traditional water cooking. The best cooking time for steaming was $7 \mathrm{~min}$, and the rental cooking time of microwave cooking was $5 \mathrm{~min}$.

\section{Discussion}

\subsection{Low Temperature with 1-MCP Delayed Yellowing and Nutrient Loss of Broccoli Florets}

Color mainly determines the consumer purchasing power of a food product [30]. Low-temperature storage or 1-MCP treatment can delay chlorophyll degradation in florets, and the combination of $0{ }^{\circ} \mathrm{C}$ storage condition and 1-MCP treatment resulted in the lowest rate of decrease in chlorophyll content [31-33]. This result indicates the additive effects of both treatments (Figure 1). GSL or sulforaphane content could represent high nutritional value, and the metabolism is influenced by many factors, such as environmental condition, fertilization level, and storage strategies [34-37]. In the present study, the total GSL, AGS, and IGS contents remarkably decreased in the storage samples compared with fresh florets and were higher under $0{ }^{\circ} \mathrm{C}$ than 4 and $10{ }^{\circ} \mathrm{C}$ storage conditions (Figure 2). The results are explained below.

First, GSLs contact myrosinase, and was hydrolyzed to produce isothiocyanates (ITCs), when a plant tissue is damaged by mechanical wounding (e.g., chewing, chopping, or cutting) or by insects or humans [38]. The GSL content of broccoli floret significantly decreased when stored at $20^{\circ} \mathrm{C}$ for five days, and this finding can be attributed to the observed activity of myrosinase [38]. Further, myrosinase activity decreased under $0{ }^{\circ} \mathrm{C}$ storage condition more than that under 4 or $10^{\circ} \mathrm{C}$, thus maintaining high levels of GSLs under lower temperature caused by the inhibited glucosinolate-myrosinase system. Subsequently, the GSL content was higher under $0{ }^{\circ} \mathrm{C}$ storage than that at 4 and $10{ }^{\circ} \mathrm{C}$ storage conditions (Figure 2).

Second, with increased storage time, tissue senescence was aggravated, and cellular integrity was interrupted in broccoli florets, thus facilitating the contact between myrosinase and GSLs and hydrolyzing the GSLs. Our results indicated that 1-MCP can inhibit the decrease in GSL content (Figure 2). 1-MCP delays tissue senescence by activating antioxidant enzyme systems, inhibiting membrane lipid peroxidation and ethylene signal transduction, and inhibiting respiration, thereby playing a significant role in maintaining cell membrane integrity $[21,22,31]$. Our results indicated that $1-\mathrm{MCP}$ can inhibit the decrease in GSL content (Figure 2). The possible reason was that cell membrane integrity was protected by 1-MCP, and the contact between myrosinase and GSLs was prevented.

Third, the content of GRA, as precursor substance of sulforaphane, decreased with increasing storage time (Figure $3 \mathrm{~A}$ ). As a result, sulforaphane content had a decreasing trend with increasing storage time $[39,40]$. In addition, the GRA contents decreased by $55.3 \%$ and $52.7 \%$ under $10{ }^{\circ} \mathrm{C}$ storage condition, resulting in low GRA contents during $10{ }^{\circ} \mathrm{C}$ storage [38]. The results presented in Figure 3B show that the treatment of broccoli florets with 1-MCP significantly delayed the decrement in sulforaphane production. This result may be attributed to the increase in the substrate (GRA) in the broccoli florets treated with 1-MCP.

\subsection{Steaming or Microwaving Reduced Nutrient Loss of Broccoli Florets}

Cooking affects GSL composition and content of Brassica vegetables, and the effects depend on processing manner, cooking time, vegetable type, and degree of damage in cell tissues [1]. In the present study, the GSL content decreased, and significant rebound of IGS was observed after a cooking time of $3 \mathrm{~min}$, and a peak was observed at $7 \mathrm{~min}$ of 
steaming (Figure 4). Similar results were found in the microwave treatment, and a peak occurred after a cooking time of $7 \mathrm{~min}$ for 'Yanxiu' and $5 \mathrm{~min}$ for 'Xianglv No.3' (Figure 4). Therefore, the GSL content during cooking is closely related to heating time. Cooking and heating may increase compound extractability [41]. In comparison with steaming and microwaving, boiling led to considerable GSL loss, and this finding corresponded well with previous studies [23]. GSLs are water-soluble compounds and are usually lost during conventional cooking due to leaching into surrounding water caused by cell lysis [24]. In the present work, GSL content significantly decreased to a higher degree during boiling than during steaming and microwaving (Figure 4). Therefore, boiling has an adverse effect on GSL content due to cell leakage.

The sulforaphane level in broccoli reflected two opposing physiological processes, namely, hydrolysis from GSLs by myrosinase and thermal degradation to volatile compounds. Endogenous myrosinase accelerates GRA hydrolysis caused by cell lysis under continuous thermal processes during cooking, while high temperature inactivates myrosinase activity and reduces hydrolysis rate. In the present study, the sulforaphane level first decreased, and then increased, and finally decreased under the three cooking methods (Figure 5). The increase in sulforaphane content can be attributed to high temperature, which may have dramatically reduced myrosinase activity, but the retained GRA can still be converted into sulforaphane by the enzymatic activity of the microbiota [42]. Sulforaphane was more stable than myrosinase [43]. As a result, sulforaphane accumulated under continuous myrosinase hydrolysis and low thermal degradation. With increased cooking time, GRA content significantly decreased, and high temperatures accelerated the generation of some volatile compounds from sulforaphane [44]. This process caused the decline in sulforaphane content. Notably, sulforaphane content had a peak at $7 \mathrm{~min}$ of steaming and at 5 min of microwaving (Figure 5). This result can help in the selection of the cooking method and time for retaining high sulforaphane level.

\section{Conclusions}

In this study, the contents of chlorophyll, total GSLs, AGS, IGS, and sulforaphane in broccoli floret of two varieties decreased with prolonged storage time. The $0{ }^{\circ} \mathrm{C}$ storage condition combined with 1-MCP treatment exerted the best effect for preserving chlorophyll, GSLs, and sulforaphane. After 6 days of storage, $58.8 \%$ and $77.2 \%$ of the sulforaphane contents of the two varieties were preserved under the $0{ }^{\circ} \mathrm{C}$ storage condition. 1-MCP treatment increased sulforaphane content, but the effect differed among varieties. The cooking experiment indicated that steaming and microwaving can effectively preserve the quality and increase the sulforaphane content of broccoli florets. Moreover, cooking time has a significant effect on sulforaphane content. The highest sulforaphane content was retained at $7 \mathrm{~min}$ of steaming or $5 \mathrm{~min}$ of microwaving. These results can provide valuable information for the storage and cooking of broccoli sprouts.

Supplementary Materials: The following materials are available online at https:/ / www.mdpi.com/ article/10.3390/horticulturae7120519/s1, Figure S1: Effects of storage temperature and 1-MCP treatment on individual GSL content in broccoli florets. $4 \mathrm{OH}$ content ((A): Yanxiu, (B): Xianglv No.3), GBC content ((C): Yanxiu, (D): Xianglv No.3), 4ME content ((E): Yanxiu, (F): Xianglv No.3), NEO content ((G): Yanxiu, (H): Xianglv No.3), GER content ((I): Yanxiu, (J): Xianglv No.3), IBE content ((K): Yanxiu). 4OH: 4-hydroxyglucobrassicin; GBC: Glucobrassicin; 4ME: 4-Methoxyglucobrassicin; NEO: Neoglcobrassincin; GER: Glucoerucin; IBE: Glucoiberin. Storage temperature: 10, 4, and $0{ }^{\circ} \mathrm{C}$; control: without 1-MCP treatment; 1-MCP: 1-MCP treatment; FB: fresh broccoli florets; storage time: 2, 4, and 6 days. Error bars represent SD from storage experiments. Different letters represent the comparison among FB and all treatments $(p<0.05)$. Figure S2: Effects of cooking method on individual GSL content in broccoli florets. $4 \mathrm{OH}$ content ((A): Yanxiu, (B): Xianglv No.3), GBC content ((C): Yanxiu, (D): Xianglv No.3), 4ME content ((E): Yanxiu, (F): Xianglv No.3), NGBC content ((G): Yanxiu, (H): Xianglv No.3), GER content ((I): Yanxiu, (J): Xianglv No.3), IBE content ((K): Yanxiu). 4OH: 4-hydroxyglucobrassicin; GBC: Glucobrassicin; 4ME: 4-Methoxyglucobrassicin; NEO: Neoglcobrassincin; GER: Glucoerucin; IBE: Glucoiberin. Red lines, steaming; blue lines, microwaving; 
black lines, boiling; error bars represent SD from storage experiments. Different letters represent the comparison among different cooking methods at same time $(p<0.05)$. Table S1: Desulfated GSLs identified in broccoli florets using HPLC.

Author Contributions: Conceptualization, K.H., Q.W. and N.Z.; methodology, Y.Y., J.W. and S.M.; validation and formal analysis, Y.Y. and M.L.; investigation, Q.W. and S.W.; resources, K.H. and Q.W.; writing-original draft preparation, J.W. and S.M.; writing—review and editing, J.W., K.H. and Q.W.; visualization, Y.Y. and J.W.; supervision, K.H. and Q.W.; project administration, Y.Y. and S.M.; funding acquisition, K.H., Q.W. and J.W. All authors have read and agreed to the published version of the manuscript.

Funding: This research was funded by National Natural Science Foundation of China (No. 32072568, 32072585, 31902023), Changsha Municipal Natural Science Foundation (kq2007016), and Agricultural Science and Technology Innovation Program of CAAS (CAAS-XTCX2019025).

Institutional Review Board Statement: Not applicable.

Informed Consent Statement: Not applicable.

Data Availability Statement: The datasets generated for this study are available on request to the corresponding author.

Conflicts of Interest: The authors declare no conflict of interest.

\section{References}

1. Yuan, G.; Sun, B.; Yuan, J.; Wang, Q. Effects of different cooking methods on health-promoting compounds of broccoli. J. Zhejiang Univ. Sci. B 2009, 10, 580-588. [CrossRef]

2. Dinkova-Kostova, A.T.; Kostov, R.V. Glucosinolates and isothiocyanates in health and disease. Trends Mol. Med. 2012, 18, 337-347. [CrossRef]

3. Lage, M.Á.P.; Jiménez López, C.; Simal-Gandara, J. Glucosinolates: Molecular structure, breakdown, genetic, bioavailability, properties and healthy and adverse effects. Adv. Food Nutr. Res. 2019, 90, 305-350.

4. Martínez-Ballesta, M.; Moreno, D.A.; Carvajal, M. The physiological importance of glucosinolates on plant response to abiotic atress in brassica. Int. J. Mol. Sci. 2013, 14, 11607-11625. [CrossRef] [PubMed]

5. Matusheski, N.; Jeffery, E.H. Comparison of the bioactivity of two glucoraphanin hydrolysis products found in broccoli, sulforaphane and sulforaphane nitrile. J. Agric. Food Chem. 2001, 49, 5743-5749. [CrossRef]

6. Cai, C.; Miao, H.; Qian, H.; Yao, L.; Wang, B.; Wang, Q. Effects of industrial pre-freezing processing and freezing handling on glucosinolates and antioxidant attributes in broccoli florets. Food Chem. 2016, 210, 451-456. [CrossRef] [PubMed]

7. Valgimigli, L.; Iori, R. Antioxidant and pro-oxidant capacities of ITCs. Environ. Mol. Mutagen. 2010, 50, 222-237. [CrossRef]

8. Lippmann, D.; Lehmann, C.; Florian, S.; Barknowitz, G.; Haack, M.; Mewis, I.; Wiesner, M.; Schreiner, M.; Glatt, H.; BrigeliusFlohé, R.; et al. Glucosinolates from pak choi and broccoli induce enzymes and inhibit inflammation and colon cancer differently. Food Funct. 2014, 5, 1073-1081. [CrossRef] [PubMed]

9. Yang, G.; Lee, H.E.; Lee, J.Y. A pharmacological inhibitor of NLRP3 inflammasome prevents non-alcoholic fatty liver disease in a mouse model induced by high fat diet. Sci. Rep. UK 2016, 6, 24399. [CrossRef]

10. Traka, M.; Mithen, R. Glucosinolates, isothiocyanates and human health. Phytochem. Rev. 2009, 8, 269-282. [CrossRef]

11. Brennan, P.S.; Shewfelt, R.L. Effect of cooling delay at harvest on broccoli quality during postharvest storage. J. Food Qual. 2010, 12, 13-22. [CrossRef]

12. Ilahy, R.; Tlili, I.; Zoltán, P.; Montefusco, A.; Siddiqui, M.W.; Homa, F.; Hdider, C.; R'Him, T.; Lajos, H.; Lenucci, M.S. Pre-and post-harvest factors affecting glucosinolate content in broccoli. Front. Nutr. 2020, 7, 00147. [CrossRef] [PubMed]

13. Bell, L.; Wagstaff, C. Enhancement of glucosinolate \& isothiocyanate profiles in Brassicaceae crops: Addressing challenges in breeding for cultivation, storage, and consumer related traits. J. Agric. Food Chem. 2017, 65, 9379-9403. [PubMed]

14. Casajús, V.; Demkura, P.; Civello, P.; Lobato, M.G.; Martínez, G. Harvesting at different time-points of day affects glucosinolate metabolism during postharvest storage of broccoli. Food Res. Int. 2020, 136, 109529. [CrossRef] [PubMed]

15. Rybarczyk, A.; Hagen, S.F.; Borge, G.I.A.; Bengtsson, G.B.; Hansen, M.K.; Wold, A.-B. Glucosinolates in broccoli (Brassica oleracea L. var. italica) as affected by postharvest temperature and radiation treatments. Postharvest Biol. Technol. 2016, 116, 16-25. [CrossRef]

16. Hansen, M.; Møller, P.; Sørensen, H.; Trejo, M.C.D. Glucosinolates in broccoli stored under controlled atmosphere. J. Am. Soc. Hortic. Sci. 1995, 120, 1069-1074. [CrossRef]

17. Rodrigues, A.S.; Rosa, E.A. Effect of post-harvest treatments on the level of glucosinolates in broccoli. J. Sci. Food Agric. 1999, 79, 1028-1032. [CrossRef]

18. Ku, V.; Wills, R. Effect of 1-methylcyclopropene on the storage life of broccoli. Postharvest Biol. Technol. 1999, 17, 127-132. [CrossRef]

19. Fan, X.T.; Mattheis, J.P. Yellowing of broccoli in storage is reduced by 1-methylcyclopropene. HortScience 2000, 35, 885-887. [CrossRef] 
20. Yuan, G.; Sun, B.; Yuan, J.; Wang, Q. Effect of 1-methylcyclopropene on shelf life, visual quality, antioxidant enzymes and health-promoting compounds in broccoli florets. Food Chem. 2010, 118, 774-781. [CrossRef]

21. Fernández-León, M.F.; Fernández-León, A.M.; Lozano, M.; Ayuso, M.C.; González-Gómez, D. Different postharvest strategies to preserve broccoli quality during storage and shelf life: Controlled atmosphere and 1-MCP. Food Chem. 2013, 138, 564-573. [CrossRef]

22. Bongoni, R.; Verkerk, R.; Steenbekkers, B.; Dekker, M.; Stieger, M. Evaluation of different cooking conditions on broccoli (Brassica oleracea var. italica) to improve the nutritional value and consumer acceptance. Plant Food Hum. Nutr. 2014, 69, 228-234. [CrossRef]

23. Chiu, Y.-C.; Matak, K.; Ku, K.-M. Methyl jasmonate treatment of broccoli enhanced glucosinolate concentration, which was retained after boiling, steaming, or microwaving. Foods 2020, 9, 758. [CrossRef]

24. Gliszczyńska-Świglo, A.; Ciska, E.; Pawlak-Lemańska, K.; Chmielewski, J.; Borkowski, T.; Tyrakowska, B. Changes in the content of health-promoting compounds and antioxidant activity of broccoli after domestic processing. Food Addit. Contam. 2006, 23, 1088-1098. [CrossRef]

25. Palermo, M.; Pellegrini, N.; Fogliano, V. The effect of cooking on the phytochemical content of vegetables. J. Sci. Food Agric. 2014, 94, 1057-1070. [CrossRef] [PubMed]

26. Inskeep, W.P.; Bloom, P.R. Extinction coefficients of chlorophyll a and b in N,N-dimethylformamide and $80 \%$ acetone. Plant Physiol. 1985, 77, 483-485. [CrossRef] [PubMed]

27. Kim, Y.-B.; Li, X.; Kim, S.-J.; Kim, H.-H.; Lee, J.; Kim, H.; Sang, U.P. MYB transcription factors regulate glucosinolate biosynthesis in different organs of Chinese cabbage (Brassica rapa ssp. pekinensis). Molecules 2013, 18, 8682-8695. [CrossRef] [PubMed]

28. Schonhof, I.; Krumbein, A.; Brückner, B. Genotypic effects on glucosinolates and sensory properties of broccoli and cauliflower. Mol. Nutr. Food Res. 2010, 2010. 48, 25-33. [CrossRef]

29. Huang, K.; Lin, J.C.; Wu, Q.Y.; Yan, J.Y.; Liu, M.Y.; Zhang, S.; Xiao, W.J. Changes in sulforaphane and selenocysteine methyltransferase transcript levels in broccoli treated with sodium selenite. Plant Mol. Biol. Rep. 2015, 34, 1-8. [CrossRef]

30. Rawson, A.; Patras, A.; Kumar, T.B.; Noci, F.; Koutchma, T.; Brunton, N.P. Effect of thermal and non-thermal processing technologies on the bioactive content of exotic fruits and their products. Food Res. Int. 2011, 44, 1875-1887. [CrossRef]

31. Xu, F.; Chen, X.; Yang, Z.; Jin, P.; Wang, K.; Shang, H.; Wang, X.; Zheng, Y. Maintaining quality and bioactive compounds of broccoli by combined treatment with 1-methylcyclopropene and 6-benzylaminopurine. J. Sci. Food Agric. 2013, 93, $1156-1161$. [CrossRef] [PubMed]

32. Sharma, R.; Bhatia, S.; Kaur, P. Influence of packaging and storage conditions on biochemical quality and enzymatic activity in relation to shelf life enhancement of fresh basil leaf. J. Food Sci. Technol. 2018, 55, 3199-3211. [CrossRef] [PubMed]

33. Zhan, X.; Zhu, Z.; Sun, D.-W. Effects of pretreatments on quality attributes of long-term deep frozen storage of vegetables: A review. Crit. Rev. Food Sci. 2018, 59, 743-757. [CrossRef]

34. Björkman, M.; Klingen, I.; Birch, A.N.E.; Bones, A.M.; Bruce, T.J.A.; Johansen, T.J.; Meadow, R.; Mølmann, J.; Seljåsen, R.; Smart, L.E.; et al. Phytochemicals of Brassicaceae in plant protection and human health-influences of climate, environment and agronomic practice. Phytochemistry 2011, 72, 538-556. [CrossRef]

35. Guo, L.; Yang, R.; Wang, Z.; Guo, Q.; Gu, Z. Glucoraphanin, sulforaphane and myrosinase activity in germinating broccoli sprouts as affected by growth temperature and plant organs. J. Funct. Foods 2014, 9, 70-77. [CrossRef]

36. Hanschen, F.S.; Schreiner, M. Isothiocyanates, nitriles, and epithionitriles from glucosinolates are affected by genotype and developmental stage in Brassica oleracea varieties. Front. Plant Sci. 2017, 8, 01095. [CrossRef] [PubMed]

37. Pellegrino, R.; Wheeler, J.; Sams, C.E.; Luckett, C.R. Storage time and temperature on the sensory properties broccoli. Foods 2019, 8, 162. [CrossRef]

38. Bones, A.M.; Rossiter, J.T. The enzymic and chemically induced decomposition of glucosinolates. Phytochemistry 2006, 67, 1053-1067. [CrossRef] [PubMed]

39. Zinoviadou, K.; Galanakis, C.M. Glucosinolates and respective derivatives (isothiocyanates) from plants. Food Bioact. 2017, 3-22.

40. Li, R.; Zhu, Y. The primary active components, antioxidant properties, and differential metabolite profiles of radish sprouts (Raphanus satious L.) upon domestic storage: Analysis of nutritional quality. J. Sci. Food Agric. 2018, 98, 5853-5860. [CrossRef]

41. Oliviero, T.; Verkerk, R.; Dekker, M. Effect of water content and temperature on glucosinolate degradation kinetics in broccoli (Brassica oleracea var. italica). Food Chem. 2012, 132, 2037-2045. [CrossRef]

42. Fahey, J.W.; Wehage, S.L.; Holtzclaw, W.D.; Kensler, T.W.; Egner, P.A.; Shapiro, T.A.; Talalay, P. Protection of humans by plant glucosinolates: Efficiency of conversion of glucosinolates to isothiocyanates by the gastrointestinal microflora. Cancer Prev. Res. 2012, 5, 603-611. [CrossRef] [PubMed]

43. Wu, Y.; Shen, Y.; Wu, X.; Zhu, Y.; Mupunga, J.; Bao, W.; Huang, J.; Mao, J.; Liu, S.; You, Y. Hydrolysis before stir-frying increases the isothiocyanate content of broccoli. J. Agric. Food Chem. 2018, 66, 1509-1515. [CrossRef] [PubMed]

44. Jin, Y.; Wang, M.; Rosen, R.T.; Ho, C.-T. Thermal degradation of sulforaphane in aqueous solution. J. Agric. Food Chem. 1999, 47, 3121-3123. [CrossRef] 